\title{
Asymmetric Methyl Group Labeling as a Probe of Membrane Protein Homo-Oligomers by NMR Spectroscopy
}

\author{
Supplemental Data \\ Nathaniel J. Traaseth ${ }^{1}$, Raffaello Verardi ${ }^{1}$, Gianluigi Veglia ${ }^{1,2^{*}}$ \\ Departments of Biochemistry, Molecular Biology, and Biophysics ${ }^{1}$ and Chemistry ${ }^{2}$, University \\ of Minnesota, Minneapolis, MN 55455 \\ RECEIVED DATE (automatically inserted by publisher); E-mail: veglia@ chem.umn.edu
}




\section{Supporting Materials}

\section{Sample Preparation}

Wild-type phospholamban (wt-PLN) was expressed as a fusion protein with maltose binding protein (MBP) in E. coli bacteria. ${ }^{1}$ Two differently labeled PLN samples were prepared: 1) $\left[\mathrm{U}_{-}{ }^{2} \mathrm{H},{ }^{12} \mathrm{C},{ }^{14} \mathrm{~N}\right]$ and ${ }^{13} \mathrm{CH}_{3}$ at the $\mathrm{Il}{ }^{\delta 1}$ and 2) $\left[\mathrm{U}_{-}{ }^{2} \mathrm{H},{ }^{12} \mathrm{C},{ }^{14} \mathrm{~N}\right]$ and ${ }^{13} \mathrm{CH}_{3}$ at the $\mathrm{Leu}^{81 / 2} / \mathrm{Val}^{\gamma 1 / 2}$. This labeling scheme provides well-resolved resonances for the two samples, where $\mathrm{Leu}^{\delta 1 / 2} / \mathrm{Val}^{\gamma / 2}(24.4 \pm 2.3 / 21.4 \pm 2.5 \mathrm{ppm})$ have chemical shifts significantly different from $\mathrm{Ile}^{\delta 1}$ (13.6 \pm 2.9 ppm; BMRB data bank, http://www.bmrb.wisc.edu).

To ensure perdeuteration, PLN was grown in $99.9 \% \mathrm{D}_{2} \mathrm{O}$ water and perdeuterated nutrients. Unlabeled ${ }^{14} \mathrm{~N}$ ammonium chloride was the sole source of nitrogen. Prior to expression with IPTG (30-45 min), two different precursors, 2-ketobutyric acid-4- ${ }^{13} \mathrm{C}, 3,3-\mathrm{d}_{2}$ (for Ile sample) and 2-keto-3-(methyl- $\mathrm{d}_{3}$ )-butyric acid-4- ${ }^{13} \mathrm{C}$ (for Val and Leu sample) were added to two separate growths $(50 \mathrm{mg} / \mathrm{L})$. Precursors were purchased from Isotec (Sigma-Aldrich). PLN was purified using an amylose binding resin followed by cleavage of MBP with tobacco etch virus (TEV) as previously described. ${ }^{1}$ Each growth and purification yielded $\sim 5 \mathrm{mg}$ PLN/L and resulted in $\sim 99.9 \%$ deuteration as assessed by matrix-assisted laser desorption/ionization time-of-flight (MALDI-TOF) mass spectrometry.

After purification, the two PLN samples were mixed to a 1/1 molar ratio and dissolved in $6 \mathrm{M}$ guanidine hydrochloride, $300 \mathrm{mM}{ }^{2} \mathrm{H}_{38}$ dodecylphosphocholine (DPC), $25 \mathrm{mM}$ phosphate (pH 6.0), $50 \mathrm{mM}$ 2-mercaptoethanol, and $125 \mathrm{mM} \mathrm{NaCl}$. The samples were heated to $60{ }^{\circ} \mathrm{C}$ for 2 hours, allowing for stochastic mixing of the two differently labeled PLN molecules. The samples were then dialyzed to remove all denaturant. Final monomeric concentration of PLN was 0.7 $\mathrm{mM}$. 
NMR Spectroscopy

A constant-time HSQC (CT-HSQC) $)^{2,3}$ and a modified version of the methyl-NOESY experiment $\left({ }^{13} \mathrm{C}-\omega_{1},{ }^{13} \mathrm{C}-\omega_{2},{ }^{1} \mathrm{H}-\omega_{3}\right){ }^{4}$ were performed (see Figure 1). The experiments were performed at $40{ }^{\circ} \mathrm{C}$ at a ${ }^{1} \mathrm{H}$ Larmor frequency of $599.54 \mathrm{MHz}$ with a Varian VNMRS spectrometer. Due to the ${ }^{13} \mathrm{C}$ labeling at only methyl groups, the methyl-NOESY pulse sequence was simply modified to replace all shaped pulses on ${ }^{13} \mathrm{C}$ with square pulses centered at $19 \mathrm{ppm}$ as well as to remove pulses on deuterium or other aliphatic carbons. For the CT-HSQC, a matrix consisting of $(100,512)$ complex points, spectral widths of $(2500 \mathrm{~Hz}, 6000 \mathrm{~Hz})$ and acquisition times of (40 ms, $85.3 \mathrm{~ms})$ was recorded. The methyl-NOESY experiment was recorded in a constant-time fashion in $\mathrm{t}_{1}$ yielding a matrix consisting of $(82,60,512)$ complex points, spectral widths of $(2500 \mathrm{~Hz}, 2500 \mathrm{~Hz}, 6000 \mathrm{~Hz})$ and acquisition times of (32.8 ms, $24 \mathrm{~ms}, 85.3 \mathrm{~ms})$. Mixing times of 200,300, and $400 \mathrm{~ms}$ were acquired with a recycle delay of $1.5 \mathrm{~s}$ and 8 scans for a total experiment time of $93 \mathrm{hr}$. 


\section{Supporting Figures}

\section{Figure 1}

Methyl-NOESY pulse sequence ${ }^{4}$ used to measure intermonomer NOEs. Narrow and wide square pulses correspond to $90^{\circ}$ and $180^{\circ}$ tip angles. Unless indicated otherwise, pulses have phase $\mathrm{x}$. Carrier frequencies were set at $4.6 \mathrm{ppm}$ (water) for ${ }^{1} \mathrm{H}$ and $19 \mathrm{ppm}$ for ${ }^{13} \mathrm{C}$ (centered between Val/Leu and $\mathrm{Ile}_{\delta 1}$ methyl groups). RF $\mathrm{B}_{1}$ field strengths used were 45 and $19 \mathrm{kHz}$ for ${ }^{1} \mathrm{H}$ and ${ }^{13} \mathrm{C}$, respectively. Delays used were: $\tau_{\mathrm{a}}-1.8 \mathrm{~ms}, \tau_{\mathrm{mix}}-400 \mathrm{~ms}, \mathrm{~T}-17 \mathrm{~ms}$. Phases were set to: $\phi_{1}$ $\{2(\mathrm{x}), 2(-\mathrm{x})\}, \phi_{2}\left\{4(\mathrm{x}), 4(-\mathrm{x}), \phi_{3}\{\mathrm{x},-\mathrm{x}\}, \phi_{\text {rec }}\{\mathrm{x}, 2(-\mathrm{x}), \mathrm{x},-\mathrm{x}, 2(\mathrm{x}),-\mathrm{x}\}\right.$. Gradient times (strengths) were: $\mathrm{g} 1-0.5 \mathrm{~ms}(10 \mathrm{G} / \mathrm{cm}), \mathrm{g} 2-0.4 \mathrm{~ms}(5 \mathrm{G} / \mathrm{cm}), \mathrm{g} 3-1.0 \mathrm{~ms}(15 \mathrm{G} / \mathrm{cm}), \mathrm{g} 4-0.4 \mathrm{~ms}(18$ $\mathrm{G} / \mathrm{cm}), \mathrm{g} 5-0.75 \mathrm{~ms}(15 \mathrm{G} / \mathrm{cm}), \mathrm{g} 6-0.5 \mathrm{~ms}(6 \mathrm{G} / \mathrm{cm}), \mathrm{g} 7-1.0 \mathrm{~ms}(8 \mathrm{G} / \mathrm{cm}), \mathrm{g} 8-0.2 \mathrm{~ms}(7$ G/cm), g9 - $0.5 \mathrm{~ms}(10 \mathrm{G} / \mathrm{cm}), \mathrm{g} 10-0.75 \mathrm{~ms}(-15 \mathrm{G} / \mathrm{cm}), \mathrm{g} 11-0.7 \mathrm{~ms}(8 \mathrm{G} / \mathrm{cm})$.

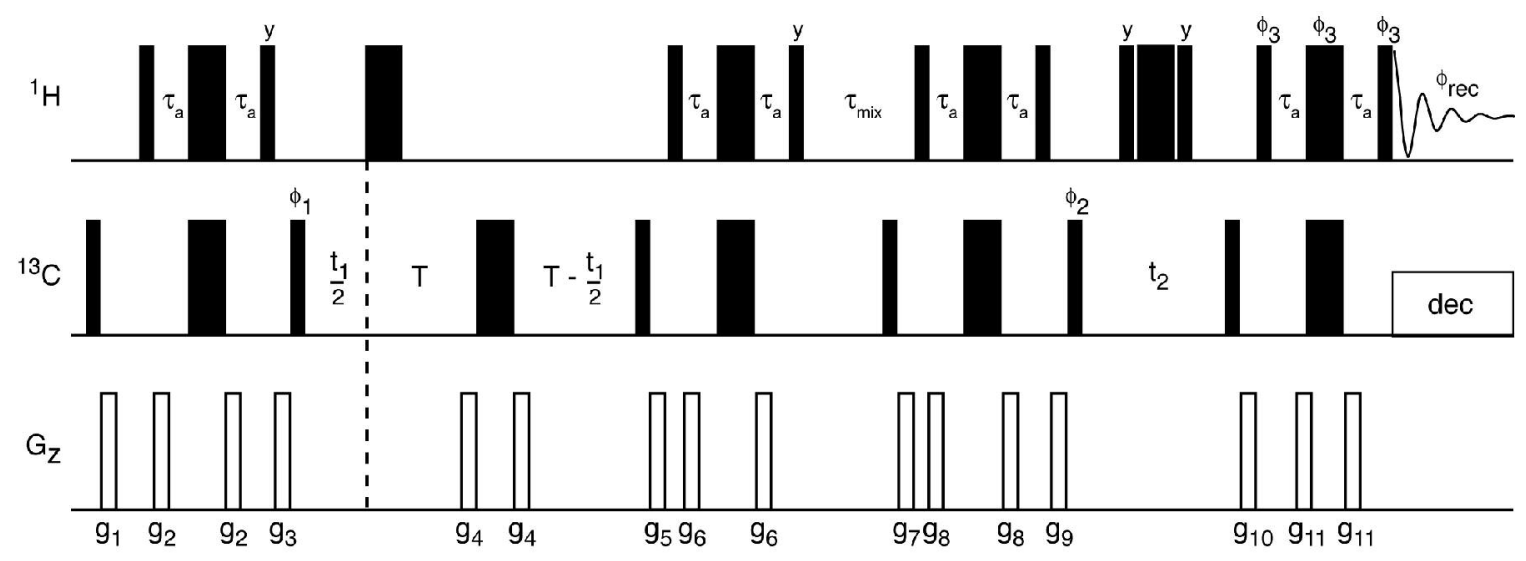




\section{Figure 2}

Additional strip plots showing intermonomer NOEs detected for pentameric PLN (similar to Figure $2 \mathrm{~A}$ in the communication). ${ }^{13} \mathrm{C}-\omega_{1} /{ }^{1} \mathrm{H}-\omega_{3}$ strip plots showing ${ }^{13} \mathrm{C}-\omega_{2}$ planes corresponding to three NOEs: Ile $33^{\mathrm{d} 1}$ to $\mathrm{L} 37^{\mathrm{d} 1}$, Ile $47^{\mathrm{d} 1}$ to $\mathrm{L} 52^{\mathrm{d} 2}$, and Ile $47^{\mathrm{d} 1}$ to $\mathrm{L} 44^{\mathrm{d} 2}$. The green peaks are the intermolecular NOEs while the red and blue peaks are diagonal peaks for Ile and Leu, respectively. The dashed lines connect the NOEs to the diagonal peaks.
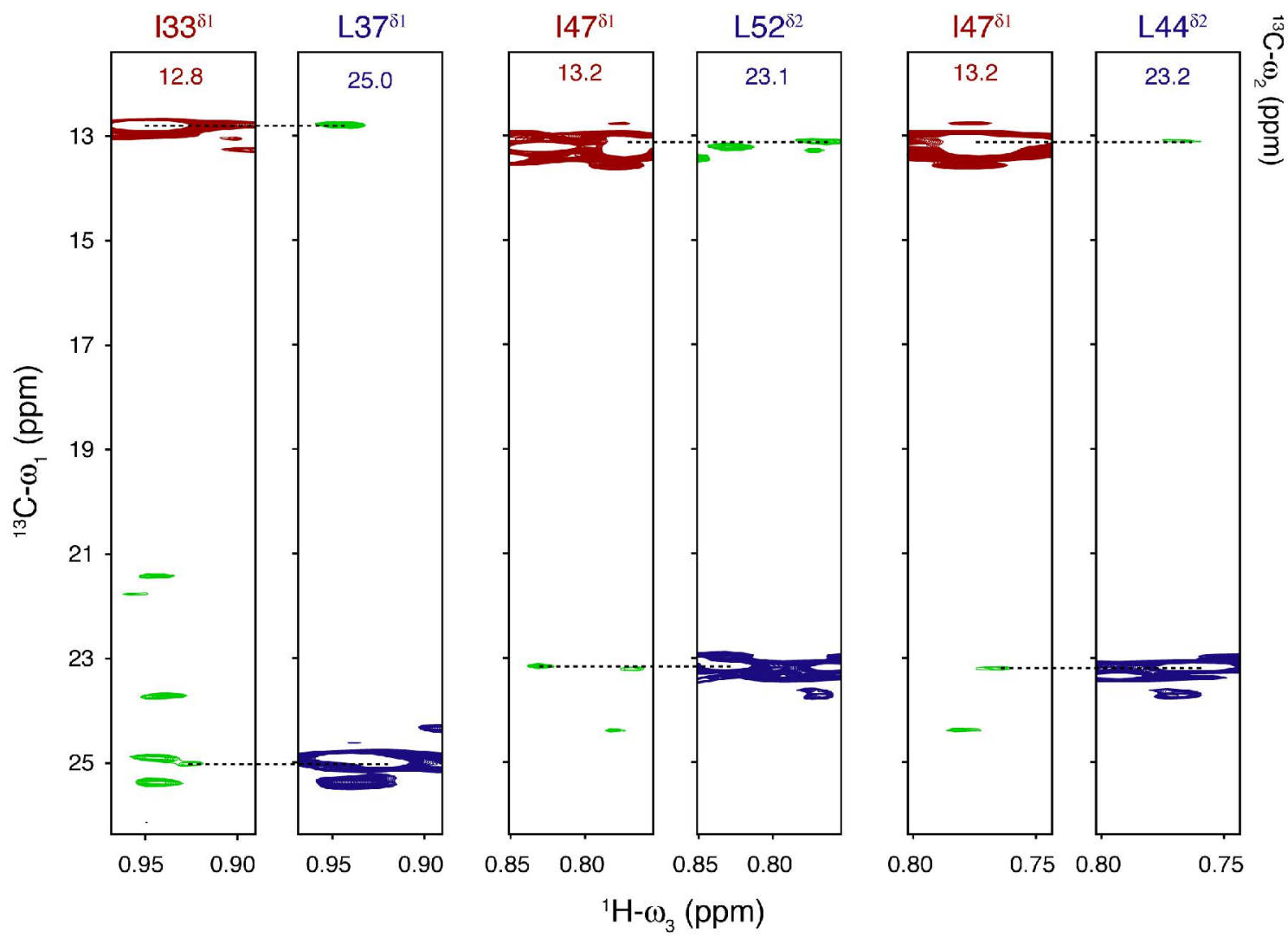


\section{Figure 3}

Isotopic labeling scheme on the pinwheel model of PLN ${ }^{5,6}$ indicating intermonomer NOEs with yellow dashed lines. The red monomer of PLN is labeled $\left[\mathrm{U}-{ }^{2} \mathrm{H},{ }^{12} \mathrm{C},{ }^{14} \mathrm{~N},{ }^{13} \mathrm{CH}_{3}-\mathrm{Ile}^{\delta 1}\right]$, while the blue monomer is labeled $\left[\mathrm{U}-{ }^{2} \mathrm{H},{ }^{12} \mathrm{C},{ }^{14} \mathrm{~N},{ }^{13} \mathrm{CH}_{3}-\mathrm{Val}^{\gamma 1,2},{ }^{13} \mathrm{CH}_{3}-\mathrm{Leu}^{\delta 1,2}\right]$. Due to the precursor chosen only one of the methyl groups in the Val and Leu sample is ${ }^{13} \mathrm{CH}_{3}$. For simplicity, NOEs are shown for either $\mathrm{Leu}^{\delta 1}$ or Leu ${ }^{\delta 2}$ although in most cases both NOEs are detected.

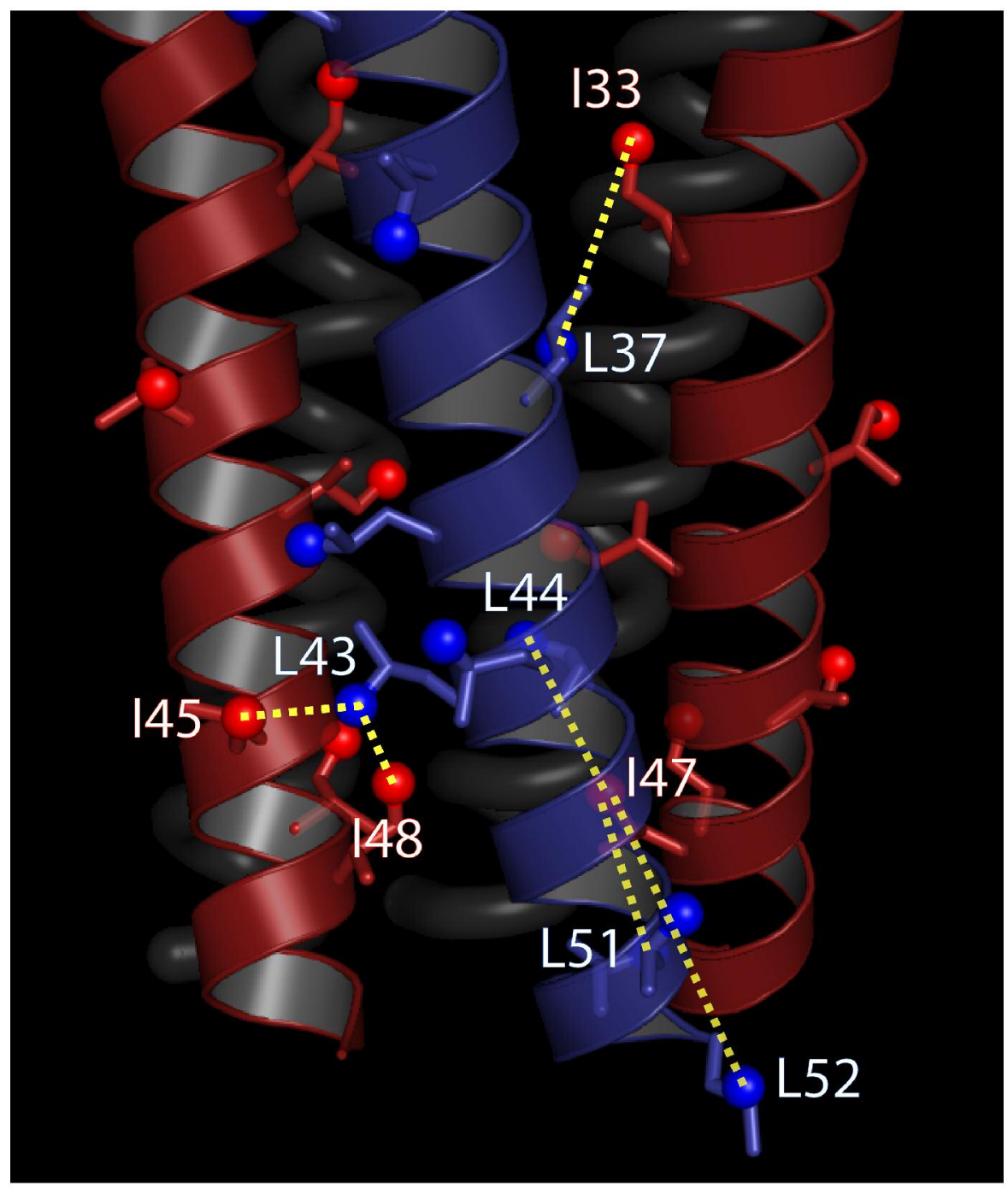




\section{References}

(1) Buck, B.; Zamoon, J.; Kirby, T. L.; DeSilva, T. M.; Karim, C.; Thomas, D.; Veglia, G. Protein Expr. Purif. 2003, 30, 253-61.

(2) Vuister, G. W.; Bax, A. J. Magn. Reson. 1992, 98, 428-435.

(3) Santoro, J.; King, G. C. J. Magn. Reson. 1992, 97, 202-207.

(4) Zwahlen, C.; Gardner, K. H.; Sarma, S. P.; Horita, D. A.; Byrd, R. A.; Kay, L. E. J. Am. Chem. Soc. 1998, 120, 7617-7625.

(5) Robia, S. L.; Flohr, N. C.; Thomas, D. D. Biochemistry 2005, 44, 4302-4311.

(6) Traaseth, N. T.; Verardi, R.; Torgersen, K. D.; Karim, C. B.; Thomas, D. D.; Veglia, G. Proc. Natl. Acad. Sci. 2007, 104, 14676-14681. 